\begin{abstract}
811.163.41'367.625
811.163.41:929 Белић А. 81'1(497.11 Београд)"19"

https://doi.org/10.18485/msc.2018.47.3.ch4

\author{
Јелена Р. ЈОВАНОВИЋ СИМИЋ \\ Филолошки факултет \\ Универзитета у Београду
}

\section{УЧЕЊЕ А. БЕЛИЋА И БЕОГРАДСКЕ ЛИНГВИСТИЧКЕ ШКОЛЕ О ЗНАЧЕЬУ И УПОТРЕБИ ГЛАГОЛСКИХ ВРЕМЕНСКИХ ОБЛИКА}

\footnotetext{
Наука о употреби личних глаголских облика - као и остале лингвистичке дисциплине код Срба - тек је са ступањем Александра Белића на научну сцену закорачила крупним кораком ка решавању суштинских питања. После њега овим се питањима бавило више истраживача него било којом парцијалном проблематиком у језичкој науци код нас. Белић је истакао идеју о тзв. индикативу, релативу и модусу, и те три категорије чине окосницу свих даљих истраживања.
}

Кључне речи: глаголско време, глаголски начин, индикатив, модус, квалификатив

1. Кад кажемо 'београдска лингвистичка школа', мислимо на најпре на А. Белића и његовог претходника Љ. Стојановића, па затим и Белићеве настављаче, као што су београдски стручњаци М. Стевановић, И. Грицкат и др. Овима би се могли придружити J. Вуковић и његови ученици у Сарајеву, али услед обима грађе издвојићемо анализу њиховог рада у посебан текст. Основу њихових научних ставова чини Белићево учење о индикативу, релативу и модусу.

2. Љ. Стојановић се осврнуо на природу глаголских облика у реченици у студији коју је Белић објавио у другом броју свог часописа Јужнословенски филолог; овај је часопис затим, током готово целог двадесетог века, одиграо најзначајнију улогу у формулисању и ширењу Белићевих идеја о језику и науци о језику. Размотрићемо у кратким цртама Стојановићев рад. Приступајући теми о глаголским облицима, већ на почетку рада Стојановић изјављује да му је 'намера' - „само да одредим њихова значења у данашњем српском језику, и то више по свом језичком осећању него по томе како их поједини писци употребљавају”. Рођењем (у Ужицу 1860, умро у Прагу 1930)

\footnotetext{
*jelenajo@bitsyu.net
} 
из родне куће понео је заиста изванредно херцеговачко језичко осећање, а бавећи се интензивно Вуковим списма - он је то осећање могао само још боље изоштрити. Ипак се индивидуално језичко осећање не може мерити са колективним, па се одсуство анализиране грађе мора узети за недостатак Стојановићева рада.

2.1. Општом дефиницијом Стојановић утврђује примарну репартицију облика за исказивање временских односа:

Глаголска радња (ту се подразумева и стање и бивање) врши се у време које делимо на садашњост, прошлост и будућност. Али се време састоји из непрекидног низа тренутака од којих један чим настане одмах и прође да уступи место другом, други трећем и тако даље у бесконачност, и како се тренуци не могу мерити, то праве садашњости и нема, већ је све или прошлост или будућност. - Садашњошћу зовемо један одсек времена, док говоримо, и она је дакле састављена из извесног броја тренутака који су прошли (од како смо почели говорити) и извесног броја тренутака који ће наступити (док не свршимо говор) (Стојановић 1921: 188).

Овакво схватање садашњости, видеће се из каснијих наших објашњења, конципирано је доста механички: говорни акт само пада у садашњу ситуацију, али није увек одлучујући фактор у одређивању њених граница, не бар у општој перспективи како Стојановић на то гледа. Садашњост, из другог правца посматрана, не може се изједначити са трајањем говорне активности, јер увек обухвата друкчији, по правилу недовољно одређен период времена у који пада и говорна активност ('говорна ситуација'), али се не поклапа са њом.

2.2. Сем поделе времена на одсеке, постоји још један битан моменат у значењу временских облика: то је чињеница да за одређење времена у којем се догађа 'радња' мора постојати некакав координатни почетак, неки временски ослонац од којега се полази. С тим у вези постоје две могућности одређења времена, и две категорије временских односа - 'прави' и 'релативни'. Аутор је свестан те чињенице, и покушава је дефинисати:

Разуме се да садашњост, прошлост и будућност може бити права и релативна, т. j. према [времену говорења, или према] некој другој радњи (Стојановић 1921: 188).

2.3. Стојановић добро осећа разлику између временских димензија самог догађаја, и односа у којима се остварује. Ти односи не подлежу квантификацији:

Глаголским се облицима не показује колико траје садашњост, прошлост или будућност (т. j. вршење радње у садашњости, прошлости или будућности), већ се само констатује факт вршења радње глаголске у једном од та три времена, н. пр.: радим, (радио сам, радићу). Ограничење трајања радње глаголске може бити прецизно одрећено речима које значе меру времена [...] (Стојановић 1921: 188).

Глаголским се облицима исто тако не показује ни размак времена између садашњости и прошлости с једне и садашњости и будућности с друге стране, већ се само констатује факт да се радња вршила у прошлости или да ће се вршити у будућности [...] (Стојановић 1921: 188). 
Не показује, дакле, перфект ближу, а аорист даљу прошлост, већ оба облика показују само прошлост, а колико је она удаљена од садашњости, то се показује на други начин [...] (Стојановић 1921: 189).

Да је боље схваћен Стојановићев став о томе, избегле би се велике недоумице око значења аориста и имперфекта, да ли означавају блиску, даљу прошлост итд. Ни пређашња, а и ни било која друга времена немају уграђен индикатор удаљености радње од времена према којем се управљају.

2.4. Интересантно је објашњење значења презента за садашњост:

Као што се вршење радње имперфективних глагола може догодити у садашњости - док се говори - може се догодити и извршење радње перфективних глагола; али како је она тренутна, чим је настала одмах је и прошла, то се она и не исказује презентом (не може се н. пр. рећи: гле, ти напишеш писмо; ене, оспе се зид, јер то и није граматичка садашњост, и ако се догодила док се говори, већ прошлост, и исказује се на исти начин као да се у прошлости догодила: ти јуче написа писмо, јуче се осу зид (Стојановић 1921: 189-190).

И ова Стојановићева мисао - о перфективном презенту за садашњост - неоправдано је остала без одјека у каснијим истраживањима. А он је био на корак од једне истине која ником није пала у очи. Наиме, ако „Гле, ти напишеш писмо" и није акцептабилна реченица кад је изговорена сама, онда јесте кад је праћена додатном, нпр.: „Гле, ти напишеш писмо па га поцепаш”; или: „Гле, оспе се зид и дигне се прашина!” Друга је ствар да ли је презентом обухваћено и време говорног акта или не. (Тиме је сугерирана мисао о могућем разграничењу говорног акта, говорног тренутка, времена говорења у стриктном значењу како га управо схвата Стојановић или сл., и садашњости, говорне ситуације и сл.)

2.5. Стојановићу је познат појам 'свевремености', и разлика у начину на који се на њу указује:

[...] презент [...] Сава утиче у Дунав [...] поред темпоралног значења садашњости има и значење да се радња уопште врши без обзира на време кад то бива; њиме се дакле утврђује факт вршења неке радње (Стојановић 1921: 190).

Кад се н. пр. каже: зрела воћка сама пада (/падне), тиме се не вели да се радња падања врши онда када се о томе говори, т. ј. у садашњости, већ кад је воћка зрела, и да то бива увек кад год сазри (Стојановић 1921: 190).

2.5. Стојановићево мишљење о најсложенијој проблематици значења и употребе глаголских времена - о значењу и употреби аориста и имперфекта - може такође бити од интереса и за данашњег истраживача:

Имперфектом се истиче трајање глаголске радње у прошлости, и он се нарочито употребљава кад се за време трајања те радње догоди или се догађа и каква друга радња: Док се ми томе чуђасмо и коње товарасмо, не лези, враже! ето ти пудара од онијех винограда (Стојановић 1921: 191).

Аорист показује један тренутак глаголске радње. Код имперфективних глагола тај тренутак који се аористом исказује јесте тренутак свршетка глаголске радње [...] (Стојановић 1921: 192).

[...] кад је потребно нарочито истаћи извршеност радње у прошлости, мора се употребити перфект, и не може се заменити аористом и имперфектом. Н. пр.: Ти си моја жена, 
тако је зар бог судио. - Кад тамо, а то помија ни капи, а око валова суха земља, нису истекле [...] - Идући тако нађе у пољу једног човека ђе је упрегао у ралицу два вола и оре (Стојановић 1921: 193).

3. А. Белић (рођен и умро у Београду, 1876-1960) стекао је образовање у најзначајнијим светским центрима тадашње науке о језику, широко засноване на познавању порекла и историје индоевропских језика и језичке теорије утемељене на компаративном њиховом изучавању. Био је сведок и учесник снажног замаха језичке теорије подстакнуте тим изучавањем до друге половине двадесетог века, у току којег лингвистика заправо доживљава свој зенит у структуралистичким идејама и њиховом невиђеном утицају на друге научне дисциплине и на општа људска теоријска знања. Његов научни углед и утицај дају посебан печат целокупној науци о језику код Срба током XX века.

3.1. Наука о значењу и употреби глаголских облика у његовим истраживањима везана је за науку о реченици, и ово двоје посматрано је као јединствен комплекс проблема (в. Симић 1966: 2). Пошто „лични глаголски облици претстављају целе и потпуне реченице” (Белић 1998: 35), ,а пошто је немогуће одвојити значење глаголских облика од њихове употребе” („Јер од употребе зависи њихово значење”, Белић 1931, преизд. 2000: 219-220); те „да би се могло добити одређивање правог времена, мора се се значење глагола остварити, реализовати” (Белић 1941, преизд. 1998: 200). То значи у ствари да се реализација значења глаголских облика дешава заправо у реченици. „Положај у реченици и функција предиката учинили су да оне особине које се код глагола јављају у предикату постану саставни део глаголске природе, то је обележје времена, глаголског начина и, како се обично вели, глаголског рода" (Белић 1998: 200).

3.2. Белићев појмовни апарат на почетку и на крају има дихотомијски смисао. На почетку (Белић 1928, 1931) његову дихотомију чине 'индикатив' и 'релатив', а на крају 'индикатив' и 'модус' (или 'начин').

а) „Ја сматрам - пише Белић (2000: 219) у својим универзитетским предавањима - да за све словенске језике за полазну тачку треба узети ово врло просто мерило: да ли се глаголски облици по значењу своме одређују према моменту садашњости или према неком другом моменту. У првом случају имамо синтаксички индикатив, а у другом синтаксички релатив”.

(1) садашње време

имперфекат

аорист

перфекат

футур

(2) плусквамперфекат

футур егзактни могу бити у синтаксичком индикативу, и у релативу

могу бити само у синтаксичком

релативу 
(3) императив потенцијал (погодбени начин) могу бити само у синтаксичком релативу

в) Завршну фазу његових разматрања чине схватања у првој књизи лингвистичких испитивања (О језичкој природи и језичком развитку) и радовима везаним за њу:

Главна је разлика између индикатива и глаголског начина у томе што се у индикативским временима износи непосредни чист временски однос између субјекта и предиката [...], док се начинима веза између субјекта и предиката износи у нарочитом смислу: као заповест, могућност, жеља итд. (Белић 1955: 1-2).

Критерији за утврђивање и временског и начинског значења налазе се 'ван саме реченице': „то је став, оцена односа између субјекта и предиката [од стране] онога ко говори” (Белић 1998: 202).

Као што се одавде види, време глаголско показује временски однос према тренутку говора [...]: оно што се врши у време говора - то је презент, што се врши пре њега - претерит, а што се врши после њега - футур (Белић 1998: 201).

3.3. О презенту Белић изражава два различита схватања.

a) У првом од та два схватања презент се карактерише као 'реализована глаголска реч' која показује 'паралелизам са говором':

Одавде се виде три ствари: а) нису потребни никакви нарочити знаци да се обележи презент, већ је довољна његова напоредност са говором говорног лица: управо, говор говорног лица и јест реченица у првом или којем другом лицу коју оно изговара. Радња те реченице и јесте напоредна са самим изговарањем те реченице. б) Како то изговарање траје извесно време, радња у презенту не може бити никад тренутна; ако нема ничег у презенту што би показивало колико има да траје његова радња, нема такође ничега што би је ограничавало: она је неограничена, њеним обликом износи се само да траје. в) Сама по себи презентска радња је напоредна са садашњошћу у овом идеалном значењу њену, тј. у индикативу: од ове напоредности са садашњошћу - она добија значење садашњости које може постати семантично значење самог облика када то значење, добивено тим путем, веже за сам гласовни састав глаголског облика (Белић 1998: 226).

a1) Ово компликовано објашњење само по себи изазива извесну неверицу у реалност. Рекло би се већ на први поглед да је из њега изостављен неки битан моменат. И стварно се тај моменат већ појављује и у Белићевим, другим поводом формулисаним интерпретацијама - поводом проблема 'индоевропске' реченице. А тај је моменат - глаголско лице, без којега се не може разумети ни време, а ни могућност његове појаве код глаголских речи. То је чињеница да лични глаголски облик по себи може чинити самосталну, по себи функционално способну реченицу. О томе сам Белић више пута расправља, нпр. „да је основно значење праве глаголске речи у обележавању и приписивању глаголске радње као особине лицу или предмету”, и то „првобитно партиципско безвременско приписивање радње као особине” (Белић 1998: 75). То значи да је примарна функција глаголске речи 'приписивање радње', а временско одређење тога приписивања - секундарна. Развој 
те функције Белић објашњава посебно као еволуцијско напредовање општих језичких функција, нпр. појава 'лица':

Али радња у личним глаголским облицима или, боље да речемо, остварена или реализована радња, а она се у индоевропским језицима јавља увек као таква у глаголским облицима, добија три стална пратилачка момента који истичу из самог остварења или реализовања глаголске радње. - Прво је временски моменат. Свака остварена радња има одређено време [...] - Други [...] јесте могућност да се радња врши на различне начине [...] - Трећи, можда најскривенији, пратилачки моменат свих личних глаголских речи јесте место. Прво лице - значи место на којем се оно налази (стојим), тј. овде одакле говорим, дакле најближе место; друго је - наближе месту првог лица, а треће је - изван круга првих двају места.

„Латентно обележавање места - наставља Белић на истом месту - не излази само из нашег тумачења настанка заменичких речи од прилога за место, већ из саме остварености глаголске радње изражене у њену приписивању [лицу] или предмету". 'Из приписивања радње лицу' - да ли накнадно или такође у вези са настанком категорије лица од заменица - проистиче такође и категорија 'привремености', односно временска категорија каква је у крајњој линији изграђена у језику (а највероватније проистекла из временске ограничености говорног акта: „Прво лице - значи место на којем се оно налази” - само док се налази! - тј. док говори). Према томе, временски моменат латентно је садржан у самом личном наставку, и код презента се манифестује као 'привременост' везана за трајање говорног чина.

а2) Још је ближе реалности Белићево следеће објашњење, али опет уз изостанак свести о импостираности временског значења у лични наставак:

[Презентом се] приписује радња као особина: ја [сам] онај што говори, ја који говори итд. Наравно, овде треба узети и временски моменат: ја [сам онај што сада] говори[м] или сл.; али треба знати да се то време добија из саме ситуације, да се, дакле, само не обележава. Јер презент глагола не значи радњу која се објављује као да вреди за садашњост, већ он значи радњу која се врши напоредно са тренутком говора који се сматра као садашњост. „Ја пишем” значи „ја пишем [док говорим]”, а време „док говорим”, које се подразумева, јесте садашњост. Дакле, 'пишем' је садашње време само зато што се објављује самим фактом говора да се врши док се говори. (Белић 1998: 68).

а3) И конкретно, када говори о презенту, Белић (1998: 201) говори о 'значењу’ временских облика као позитивној чињеници:

[...] 'Мајка преде танку жицу' значи да она ту радњу врши онда кад се о томе говори, тј. да је радња истодобна са тренутком говора. Тај се тренутак сматра као садашњост и као временско мерило радње: оно што се врши непосредно истодобно са њим, то се налази у садашњем времену; оно што се извршило пре њега ('Мајка је прела танку жицу') - то је прошлост; и оно што се глаголом исказује - налази се у прошлом (или претериталном) времену; оним пак што се врши после тога тренутка обележава се будућност ('Мајка ће прести танку жицу').

а4) 'Истодобност', 'истовременост', 'временски паралелизам', 'симултаност' итд. - ако их схватимо у 'конкретном' смислу - представљају однос, наравно у правом смислу временски. Али као што паралелизам правих не постоји по себи, већ се огледа у постору, исто тако временски паралелизам 
не постоји по себи, већ се испољава као однос у времену. А овај је замислив као 'временски простор', односно као 'ситуација' или сл. Стога је боље садашњост дефинисати као 'садашњу ситуацију' а 'истовременост са говором' као обухваћеност говора и догађаја описаног презентом заједничком садашњом ситуацијом.

б) Али на другој страни, Белић и овако суди о презенту (1998: 553-554): „Садашње време је онда када је паралелно са моментом говора који претставља садашњост [...] али ако се такав облик не употреби према моменту говора, онда тај облик значи само констатовање вршења радње". -

Обично се вели да такав облик има значење прошлости и будућности, па се чак вели да облик презента има сва та времена, а уз то и презента. Ту се чине две нетачности: 1) тиме се претпоставља да презент има свој облик морфолошки нарочито обележен; 2) као одређено значење даје се нешто што се само потенцијално садржи у поменутим облицима. Отуда излази: а) да је т. зв. облик презента само онда презент кад се употребљава у описаној семантичко-синтаксичкој ситуацији. Зато би изван тога значења тај облик ваљало назвати само личним глаголским обликом, а како он значење има одређује се његовом употребом. Сем значења презента у наведеном случају, тај би облик добијао своје значење од употребе: он би могао бити употребљен напоредо са претериталном ситуацијом - као претерит, са футурском, као футур, без икакве временске ситуације он значи само констатовање везе субјекта са предикатом: 'Земља се окреће око своје осовине и око сунца', (то вреди као констатација за сва времена), 'Камен је тежак', 'Пас је животиња', 'Сава се улива у Дунав' итд. Одатле излази да би у глаголској системи језика ваљало предвидети и један безвременски облик. Можда би било боље сматрати само у нарочитој ситуацији тај безвременски облик као презент, иначе му дати ову широку намену.

По свему како је овде облик презента сагледан излази да је његова основна варијанта 'безвременска'. Та је варијанта - по ономе што Белић тврди, и по мишљењима које наводи - и генетски примарна. Ваља овоме приговорити да је оно што се код Белића сматра 'безвременском употребом' свевременско значење. 'Уливање Саве у Дунав' није ванвременски, већ заправо временски процес несагледивог трајања.

3.4. Врло сложено значење аориста Белић (1998: 234) објашњава поредећи га са перфектом:

[...] у реченици: 'Птице су одлетеле' саопштава се у садашњости о извршеној радњи у прошлости, тј. обележава се и стварно одмеравање [прошле] радње према садашњости. У српскохрватском аористу имамо такође два елемента: а) непосредна прошлост према садашњости и б) завршено вршење радње или моментално извршење радње (или глаголског значења). У релативу остаје само завршено вршење неке радње или њезино моментално извршење напоредо са неким тренутком у прошлости [...]: О браћо, за Бога! Ми ходисмо по гори и по сваким местима и дању и ноћу, бисмо се с људима и ударасмо на куле и дворове, и ни ода шта се не поплашисмо до ноћас од мртвих људи! Одавде јасно видимо по прилогу 'ноћас' да су се све радње у аористу ('ходисмо', 'бисмо се', 'не поплашисмо се') и да се вршила до оног тренутка кад се о њој говори ('ноћас'). Међутим у реченици: 'У то време глад и болештине поморише силан свет: није било породице, а камоли братства или племена, које не би најжешће пострадало' - јасно се види да је 'поморише' истовремено са 'у то време'; према томе, момента непосредне прошлости у том примеру релатив нема никако и не може имати.

4. М. Стевановић (Пипери, Црна Гора, 1903 - Београд, 1991), научно добро припремљен и вредан истраживач српског језика, успео је дати ве- 
лики број радова, као и синтетичко дело Савремени српскохрватски језик (Стевановић 1991), који је био полазиште за језичко образовање генерација лингвиста код нас. Стевановићеве погледе о значењу и употреби глаголских времена, изнете најпре у научно добро заснованој студији (Стевановић 1957), па онда у обимној монографији (Стевановић 1976) - овде ћемо приказати углавном према тексту у Савременом српскохрватском језику, а у једном или два случаја према тексту дела из 1957.

4.1. Стевановић, као и Белић, личне глаголске облике посматра у склопу реченице, где они у комплексу предикативних категорија испољавају своје заједничке и посебне особености: „Приписујући субјекту какву радњу, какво збивање, стање, односно расположење или особину - глагол у предикату, по правилу, узима облик са знацима предикативности (лични глаголски облик), који одређујући лице истовремено одређује граматички род и број, начин или време за кој се субјекту приписује оно што се дотичним глаголом означава" (Стевановић 1991: 572).

4.2. Даље, Стевановић је прецизно утврдио однос садашњег, прошлог и будућег времена, и то му је омогућило да тачно дефинише неке временске односе, нарочито нпр. презента и аориста.

а) Прво, он на прави начин дефинише 'говорну ситуацију', одвојивши тај појам од појма 'говорног акта' (Стевановић 1991: 579):

Може се запазити да за оријентацију у одређивању времена радње (или особине) ми узимамо временски п е р и о д го в о ре њ а, а не један тренутак, одн. моменат, због тога што су ти термини могли бити, и били су, и остају узрок многих неспоразума: од спорења око постојања садашњости, па до графиконског обележавања одакле почиње и где се завршава трајање тога временског периода [...].

\section{б) У ширем објашњењу он образлаже такву дефиницију}

Тај размак, односно временски перод говорења у свакој је прилици друкчији. Када га дефинишемо у вези с друга два лингвистички релевентна периода, с периодом прошлости и периодом будућности, долазимо до закључка да је он свакако друкчији од њих. Прошлост почиње од искона и траје до тренутка говорења, а будућност иде у бесконачност, док је садашњост само неодређеног трајања. А ова опет својом неограниченошћу може обухватити оба прва, по трајању безгранична периода. Садашњост је, нпр., и суштински и лингвистички, и кад кажемо: 'Земља се окреће око осовине', као и: 'Ено наш сусед излази из куће', иако је у првом случају временски размак дуг колико и постојање ове наше планете, а у другом траје, али ипак траје, само неколико тренутака [...] (Стевановић 1991: $580)$.

Дефиниција 'говорне ситуације' (и 'садашњости'?) какву даје Стевановић - по свему судећи најбоље одговара реалним односима од свих са којима смо се у прегледу теорија сусрели (видећемо то у даљим приказима теорије).

в) Нека прецизирања аутор је овде ипак пропустио да учини, па ћемо видети да је касније морао давати исправке на своје дефиниције. Пре свега, ваљало је утврдити однос између 'садашњости' и 'времена говорења'. Иако немерљив механичким хронометром, овај појам се ипак не поклапа, или се не поклапа бар увек, са појмом 'садашњости', јер говорни акт не мора 
трајати ни бесконачно, а ни толико колико се тренутно мисли 'садашњост'. Растегљивост 'садашњости' много је израженија него самог 'говорења', које се онда схвата као известан временски 'одсек' садашњости. Но врло је битна чињеница да говорни акт чини средиште и кључни моменат за одређивање неког времена као садашњег: садашњост је 'временски период' у чијем се центру налази 'време говорења'. 'Време говорења' служи за полазиште у одређивању и садашњости и прошлости и будућности: то је гранична тачка до које сеже прошлост и од које почиње будућност, а око које се усредсређује садашњост - без обзира на дужину трајања сваког од њих.

г) Са показаног гледишта Стевановић утврђује значајне чињенице од битне вредности за утврђивање природе глаголских облика.

(1) 'Индикатив' представља централну категорију, нпр.:

- [...] да суштина значења презента није вршење радње у садашњости, него присуство њено у време на које се мисли. А то, како се зна [...], може бити и прошлост и будућност, па дакако и садашњост. Само у последњем случају то је право, апсолутно одређивање времена; којем је оријентациона тачка временски период говорења. И то се назива индикативна употреба овог глаголског времена или просто индикатив. Такву употребу имају и сва друга глаголска времена којима је временски период говорења оријентациона тачка, тј. моменат према коме се радња (а то могу бити наравно и збивања, стања или особине, све што се глаголима казује) временски одређује (Стевановић 1991: 577).

(2) Врло важан закључак о индикативу и његовом односу према критерију за одређивање времена радње када се овај нађе у реченици Стевановић (поводом перфекта) формулише у раду о 'начину одређивања значења' (Стевановић 1957: 42):

Како се у дефиницијама о значењу перфекта, мислим - оним распострањеним, говори, - то је облик којим се констатује радња која је прошла било када пре времена говорења, а њено време ничим није одређено (по моме је мишљењу боље рећи - не мора бити одређено), што према нашем тумачењу значи да нема посредне одредбе (тј. да се она не износи између вршене, односно извршене прошле радње и констатовања њеног вршења (или извршења) у време говорења. И у томе је случају оно увек глаголско време синтаксичког индикатива. Оно је то и без обзира на чињеницу да ли је неком одредбом означено када је та радња била у прошлости. Једино радња (стање, особина) таквом одредбом не сме бити означена као прошла у односу на неко друго време.

(3) Истим поводом Стевановић (1991: 42) дефинише и појам 'релатива', као и однос тих двају појмова једног према другом:

Када је пак процес према коме се [...] означени процес одређује ма који други моменат, било у прошлости било у будућности, то је [...] релатив. Ту опет имамо временско одређивање радње, па је и то индикатив, дакле релативни индикатив, који краткоће ради називамо релативом, за разлику од правог индикатива, који, опет краткоће ради као термин употребљавамо за свако временско одређивање радње, или било чега што се временским облицима казује у односу на временски период говорења.

(4) Значајан моменат у одређивању 'индикатива' и 'релатива' представља могућност употребе временских 'оријентира' у реченици. Каткада се генерално тврди да нпр. 'временска одредба' или реченични односи који се тичу временске димензије и сличних семантичких условљавања радње 
- увек представљају услов за релативну употребу глаголских облика, нпр. у приповедању и сл. Стевановић (1957: 79), међутим, има друкчији став. Узевши у разматрање текст:

Пошто се дуго и дуго градио, отиснуо се први пут на пучину до тада највећи светски брод 'Титаник'. Здрав, снажан, поносан, он је поуздано разбијао морске вале [...] секао их је и пловио своме циљу. По броју становника он претставља скоро једну, а по уређењу и читаву једну државу која плови по мору. Ту су радње и трговине, ту су касине и клубови, забаве, разонода, штампарије, па чак и новине које излазе на броду, и усред најпоузданије пловидбе, 'Титаник' наилази на подводни брег, добија снажан и неочекиван ударац с бока и тоне [...]

Објашњење гласи „да се означеним облицима перфекта и презента као подједнако реална стварност означава нешто што је било у једном истом времену у прошлости. 'Титаник' је у томе времену 'разбијао' морске вале, 'секао' их и 'пловио', што је све речено перфектом; а баш тада, у исто време, 'претстављао је' скоро читаву једну државу, ; у то 'су' време ту 'биле' радње, трговине, штампарије и баш тада је наишао на подводни брег, 'добио' снажан ударац у бок и 'потонуо', сва ово друго је изречено облицима презента. Перфекти су, међутим, ту употребљени индикативно, приповедачки презенти пак релативно [...]".

д) Према 'индикативној', као њена супротност, стоји 'модална' употреба облика. Модуси „имају своје време, било да се изражавају облицима самих глаголских начина, било облицима глаголских времена", али по Стевановићеву мишљењу они „ипак нису временска категорија” (Стевановић 1991: 576), јер служе за изражавање „личног става говорниог лица, односно субјекта, према ономе што се субјекту његовим предикатом приписује” (Исто, 700).

4.3. Презент - „у најобичнијој функцији својој [...] означава радњу која се у време када се о њој говори": - Видите ли ако бога знате /.../, свуд се чује јека и грмљава, / свуд испод нас муње сијевају, / а нас једне само сунце грије (Његош, Горски вијенац). Правим или индикативним Стевановић између осталих сматра и неке поткатегорије тзв. 'квалификатива'. „А квалификативна употреба овог облика је врло широка; квалификативан је, у ствари, сваки презент којим се или било чему приписује каква особина”. О њима ћемо нешто дуже говорити јер су од значаја за разумевање употребе временских облика уопште.

а) „У квалификативне између осталих, или пре свих осталих, иду и презенти којима се означавају стална вршења радње, познате научне, уметничке и животном праксом утврђене истине” (Стевановић 1991: 592 и д.):

Већим делом свога тока река Дрина протиче кроз тесне гудуре између стрмих планина [...] Само на неколико места речног тока њене се обале проширују у отворене долине и стварају [...] таласасте пределе [...] - Мишад гризе, али по тлих гмиже; / сам сур оро под небо се диже. - Коме закон лежи у топузу, / трагови му смрде нечовјештвом.

б) „У свему истог карактера, дакле, индикативни презент којим се означава сталност и трајност онога што се приписује имамо у примерима с овим обликом који с њим, како каже Т. Маретић, 'казује што је на којој (сачуваној) слици или кипу или што је у којој (сачуваној) књизи или писму"”: 
На највише овијех стећака имају урезани различни ликови, на пр. с лица људи на коњма с мачевима и с копљима у руци, гдје који тјерају јелена, и већ га стигли и копљем ударили; с наличја стоје три човјека, па двојица држе међу собом крст, а трећи се ухватио за њих, као да играју [...] - Хомер у Одисеји лијепо прича о вјерној Пенелопи, Хорације у 'Посланици Пизонима' увелико хвали грчку поезију [...].

в) Следећа категорија квалификатива, по Стевановићу, обухвата случајеве у којима презент има „више индикативни него релативни” карактер. То су случајеви „где ови облици означавају радње што се врше по неком реду или обичају, по некој навици или склоности субјеката којима се те радње приписују” (Стевановић 1991: 595-596):

Амбиције и ту трују људима животе и међусобне односе, мржње тињају годинама, велике љубави ничу неочекивано и гасе се споро и жалосно. Укратко, ту има од свега помало што иначе међу људима бива, што их везује или дели, подиже или сатире [...] - Он се мало замисли, застане, па прасне [...]

У објашњењу аутор констатује да овде презенти означавају радње које се „стално понављају [...] у одређеним приликама, по навици, по обичају, и јасно је, према томе, да се овај квалификативни презент (praesens consuetudinis) не употребљава индикативно него релативно. То се може закључити и из чињенице што се у оваквој функцији употребљавају напоредо презенти несвршених и свршених глагола и што се они, штавише, међусобно могу замењивати [...]".

г) Посебан значај за нас има више узгредна него истовредном сматрана напомена (Стевановић 1991: 596-597) о једном случају који стоји сасвим по страни од осталих:

Види, види... Искидани облаци лете, застру месец, опет га открију, и зато што облаци хитају, чини ми се да месец јури (И. Секулић).

„Мислим - гласи објашњење - на овде посебно означене облике перфективног презента 'застру' и 'открију'. Из онога што се износи у широј реченичној целини, у којој су ова два презента употребљена, јасно се види да ту имамо временску ситуацију говора говорног лица [...] Али га у овоме времену говорења не застру и открију само једанпут, него у томе времену застру и открију, из тренутка у тренутак, неодређени број пута. Радње се овде понављају у времену говорења. А такве се радње означавају релативним квалификативним презентом". Ми смо горе, у вези са Стојановићевим схватањима, имали прилике изјаснити се управо о случајевима те врсте, а сада ћемо изразити неодобравање према ставу да презент који означава понављање 'у времену говорења' мора бити сврстан у категорију релатива када је глагол перфективан, а када је имперф. са значењем учесталости, и кад је синонимна ситуација (исп.: Искидани облаци лете, застиру месец, опет га откривају) - индикатива.

д) Као да никакву заједничку црту аутор не уочава између оваквих и оних типова презента који се употребљавају у пословицама: 
Јаки зуби и тврд орах сломе. - По јутру се дан познаје. - Ко се не освети, он се не посвети. - Наједанпут се храст не посијече. - Што око не види срце не зажели. - Више ум замисли него море понесе. - Вода свашта опере до црна образа.

Стевановић овако употребљене презенте сматра 'модалним'. Али значење понављања 'по обичају', дакле хабитуал, само једну од могућих интерпретација - и то далеких - има сличну са значењем 'могућег остварења'. Основни смисао је заправо репетитивност, вишекратно понављање. А оно је у неку руку упоредиво са случајевима сталног дешавања (из примера под а). Разлика је у томе што тамо анализирани презенти својим остварењем захватају и 'време говорења', док га ови искључују.

4.4. Значајно је и Стевановићево схватање о аористу, па ћемо се осврнути још на ту тему.

а) Општа дефиниција (Стевановић 1991: 631) гласи да је аорист ,једно од претериталних времена. Временски употребљен, он означава радње које су се вршиле и извршиле у прошлости, пре тренутка говора":

Аргатовах три године дана, / и ја вукох дрвље и камење, / не зарадих на ноге опанке. - Ту, на средини брзака, њихов чамац удари у нешто дрвено и тешко и одјекну тупо. То их заустави. Тек тада приметише да се сејмени гушају с неким.

б) Ово је по Стевановићу 'релативни аорист', док „индикативни аорист свршених глагола $[\ldots .$.$] означава извршење радње у времену говорења":$

Ми ево побегосмо у турску земљу, али куда ћете ви бежати. - А ево видиш да подигоше и још какву ћуприју и какву згоду и љепоту. - Сад је баш сретох на улици. - Падоше вам новине, друже.

Стевановић се позива на Мусића и његову тврдњу да се аорист употребљава, између осталог, и за садашњост. Али остаје велика недоумица како ваља разумети такав аорист и такво објашњење: зар то није презентска ситуација, из које је - на својој страни - искључен перфективни презент са значењем једнократног вршења радње? И зар онда аорист 'индикативни' није замена за њега?

4.5. Но остаје закључак да Стевановићеви ставови бар делом чине велико унапређење теорије о значењу и употреби времена. И тамо где остају нерешена питања, отвара се простор за даље истраживачке подухвате.

5. Ирена Грицкат (Београд, 1922-2009) оставила је у наслеђе нашој науци врло танане и врло добро на грађи засноване анализе већег броја појава у српском језику. Овде ће бити речи о њеној студији о перфекту без помоћног глагола (Грицкат 1954). Сводна запажања ауторка даје већ у уводу своје књиге. Ослањајући се на врло разборите интерпретације Ј. Вуковића (Јужнословенски филолог, XVII) о употреби временских облика у дијалекатској средини која представља најужу основицу књижевног језика, и А. Белића са ширих индоевропских аспеката, а служећи се широком грађом из старијих списа и савременог народног и књижевног језика, И. Грицкат долази до интересантних схватања о својој компликованој теми. Нас овде занима у првом реду савремено стање у књижевном језику. 
5.1. Најпре ауторка представља резултате Вуковићеве студије (Грицкат 1954: 6-7), па ћемо их ми преузети не упуштајући се у Вуковићев текст (јер нам се чини да је И. Грицкат добро запазила најважније појединости).

a) Најпре општа Вуковићева запажања:

У релативу „у приказивању догађаја из сопственог памћења добар причалац ће претежно употребљавати имперфекат и аорист, а у приповедању догађаја који се причају по чувењу, о догађајима из старије традиције, и у народним приповеткама преовлађује перекат ('крњи') и презент ('историски').

б) Специјалније Вуковићеве идеје о употреби перфекта без помоћног глагола ауторки су послужиле за полазиште у њеним сопственим разматрањима:

Вуковић (91-96) говори о томе да се у краћем перфекту често износе догађаји који нису везани са неким другим догађајима у прошлости, тј. када тај перфекат није у релативској употреби, већ се односи на непосредну прошлост: 'Крепала нам крава', 'Ишо ја сад по њ'. Овакви перфекти не могу се заменити са аористом, без извесне промене значења, иако су му блиски. Разлика је у томе што се краћим перфектом на слушаоца „чини утисак нечег новога, што може ићи и до најобичнијег изненађења”; „такав перфекат увек носи нагласак у реченици, а у том нагласку, мање ли више, осећа се призвук усклика". Преко наглашавања важности саопштења, тј. посредним путем, истиче се блискост моменту говора код поменутог облика. Код аориста, међутим, та блискост постоји у самом основном значењу тог граматичког времена, и у томе је разлика између њих.

в) И даље, ауторкине интерпретације Вуковићевих схватања указују како на добар осећај за значење перфекта без помоћног глагола код обоје аутора, тако и на одјеке Маретићевих идеја о рекли бисмо 'врстама излагања' ('јављање' vs. 'саопштавање'):

Да се пуни перфекат употребљава за јављање о познатима стварима, а непотпуни за јављање о непознатим види се из овог примера: 'Крепала је овца' значи 'Крепала она овца'; а 'Крепала овца' има значење 'Крепала једна овца'. С друге стране, перфектом без помоћног глагола потврђује се оно што се већ зна, а што је примљено с већим интересом.

г ) Даље ауторка с правом истиче Вуковићеве заслуге, поред извесних - по њеном мишљењу - малих заблуда око значења краћег перфекта: „Вуковић жели да објасни случајеве индикативне употребе овог облика, коју је он приметио сасвим тачно и то као први међу испитивачима, али ако је правилно уочена семантика краћег пефекта, тј. актуелност за садашњи тренутак, зашто би таква психолошка веза са садашњошћу у сфери формалног израза проузроковала супротан ефекат - губљење онога што је (с тиме се слаже и сам Вуковић) израз те везе?”

д) Остављамо читаоцу да се обавести подробније о расправи коју смо нагло прекинули, а овде је битно истаћи појмове 'актуелности за садашњи тренутак', те 'саопштавања' и 'јављања'. Све су то били још недефинисани, а врло значајни моменти битни за објашњење употребе глаголских облика.

5.2. И. Грицкат гледа на облик крњег перфекта као на фактор који изазива 'транспозицију' значења пуног перфекта: „У перфекту без помоћног глагола, 
који је по свом основном семантичком карактеру још увек перфекат, имамо извесних померања у значењу, и то различите врсте” (Грицкат 1954: 9).

Једна је транспозиција она која се, у смислу учења проф. А. Белића, назива синтаксичким релативом. Када се прошлост радње, исказана перфектом, не одмерава према правој садашњости него према другој тачци на временској линији, добива се релативски перфекат. Друга транспозиција лежи у експресивности перфекатског значења [...] У реченици као што је: 'Дошли сватови', са призвуком усклика или изненађења, како нам је тумачи Вуковић, врши се модална транспозиција, помера се начин гледања на глаголску радњу. Вуковићев пример (у саопштавању) 'Дошли сватови' значи - отприлике - 'Замислите шта се догодило: дошли су сватови!' или 'Гледај, дошли су сватови!' Видимо, дакле, да нас говорник прво позива да се, такорећи, ставимо у нов положај, да се сложимо с њиме у ставу зачуђености, па онда, са тако промењене позиције, излаже нам своју прошлу радњу (Грицкат 1954: 10).

а) Изјава о 'релативном' карактеру краћег перфекта у супротности је са оним што ауторка утврђује сагласно са Вуковићевим ставом: да овај облик има могућности да упути на прошлост и са гледишта говорникова: - 'Дошли сватови' управо је догађај прошао у односу на време говорења, према којем се директно одмерава.

б) Оно што И. Грицкат назива 'експресивношћу', а што је производ 'изненађења' или чак 'зачуђености', у ствари треба свести на нешто нижи ниво 'експресије', која има и нешто друкчији карактер. Наиме, осећај извесне наглашености, или друкчије речено: интензитета казивања, долази не од улагања емоционалног тона, или експонативне енергије, како бисмо радије рекли, већ од очитовања онога што следи за догађајем који означава перфекат: 'Пуко каиш', 'Сломила се шајбна'; 'Мила купила нове ципеле', 'Дејан дипломирао’ или сл. Сам догађај по себи као да је изван зоне чињеница на које се указује, а у тој зони је последица или резултат догађаја.

5.3. У завршним напоменама ауторка посебно скреће пажњу управо на 'резултативност' и 'експресивност' као два базична својства краћег перфекта: „Експресивна, у већој или мањој мери емфатична семантика продире у наш облик као свежа струја [...] Исто тако, уз релативско, појављује се и значење резултативности [...] (Грицкат 1954: 199).

a) И. Грицкат ове значењске компоненте види као резултат семантичког развоја крњег перфекта који прати развој формалних његових одлика. То ауторка јасно показује објашњавајући потенцирање резултативности у њему:

Лишити перфекат помоћног глагола значи - у много случајева - допринети стварању резултативног значења [...] 'Магла пала' [...] таква реченица с краћим перфектом оставља утисак отсуства акције, статичног описа. Али се ту [...] истиче резултативно значење, садашњи резултат прошле радње, слика која је настала као резултат прошле радње (Грицкат 1954: 189).

\section{б) Слично се по њој дешава и са експресивношћу:}

[...] пример [као] 'Умро краљ' [...] [не] бисмо тумачили као изразито резултативно већ као наглашено казивање, као радњу изнету у експресији. Али у исто време, мада у мањој мери, имамо и ту резултативни моменат: узвичном реченицом 'Умро краљ! Кога ћемо за краља?' износи се факат краљеве смрти која се догодила у прошлости, али се констатује да је краљ мртав и да је баш такво стање разлог за узбуђење (Грицкат 1954: 190). 
в) Експресивост и емфатичност потичу заправо из потенцираног инсистирања на 'новини', на 'посебности', 'значају', 'наглашености', 'изненадности' онога што описује перфекат, а што ауторка често истиче у анализи грађе. Нпр.:

У примерима [...] имали смо овакав случај: 'Дођем софри, а оно засели први људи'. У реченици с краћим перфектом који има резултативно значење присутан је и моменат изненађења [...] (Грицкат 1954: 190).

г) Или:

[...] краћи перфекат, стекавши значење 'новине' онога што се казује (подмета и прирока), почиње да се употребљава и онда када је у питању новина односа између подмета и прирока, новина објекта и сл. (Грицкат 1954: 195).

6. Дуго се проблемима 'синтаксе глаголских облика' бави Ж. Станојчић. Он је по свом образовању и лингвистичким уверењима члан Белићеве (и Стевановићеве) школе, али са извесним посебностима које су резултат његових сопствених настојања. Његова ћемо схватања укратко приказати према опсежној Граматици српског књижевног језика (Станојчић 2010).

6.1. 'Индикативни' презент „означава радњу, стање или збивање који се врше у време када се о њима говори": Неко и овог јутра мисли на вас (Станојчић 2010: 359).

a) 'Индикативни квалификативни' презент означава „радње, стања и збивања који се стално врше, па и у време када се о њима саопштава" (Станојчић 2010: 360).

б) Релативни 'наративни или историјски' презент упућује на „радње напоредне са неким временом (моментом, ситуацијом) у прошлости” (Станојчић 2010: 360): Пре неколико дана идемо нас двојица улицом, гледамо излоге и управо пред књижаром сретнемо Петра. - Ваља се сложити с аутором у погледу значења наведених презената.

в) 'Релативни квалификативни презент' - означава радње „што се понављају, односно врше онда кад се створе услови за њихово вршење” (Чим се разиђе један круг, он луња по дворишту као уклета душа, прилази другом кругу).

6.2. „У својој основној функцији перфекат означава да су се радња, стање или збивање (из)вршили пре времена када говорник о њима саопштава" (Станојчић 2010: 363).

6.3. 'Крњи перфекат' - „Уз информацију о (из)вршењу [...] радњи у прошлости, било кад пре времена говорења [...], носи и информацију о новости радње (стања, збивања) за читаоца (слушаоца)” (Станојчић 2010: 366).

6.4. Аорист је дефинисан прецизније него и код једног од досадашњих испитивача: „У својој основној временској употреби аорист означава радњу, стања или збивање који су се вршили, односно извршили у времену саопштавања о њима или у одређеном времену у прошлости. То значи да су и у једном и у другом случају прошле радње, стања или збивања, одређена према ситуацији говорниковог саопштавања његовим саговорницима [...]” 
(Станојчић 2010: 369): Сад је баш сретох на степеницама. - Ево, прођоше поред прозора наши другови. - До овог часа читах занимљиву књигу. - „,...] саговорници су обавештени да су дотичне радње (срести, проћи) извршене, као прошле, управо тада када се то саопштава, односно да су се вршиле (читати) до једног прошлог тренутка у времену саопштавања" (Станојчић 2010: 370).

6.5. Одавде је јесан ауторов став и према видској дисперзији облика, и односу међу видовима: видска обележја свршености/несвршености остају и у аористу нетакнута.

\section{ЛИТЕРАТУРА}

Белић 1927: Александар Белић, „О употреби времена у српскохрватском језику”, Јужнословенски филолог, VI, Београд: Институт за српскохрватски језик.

Белић 1928: Александар Белић, „О синтаксичком 'индикативу' и 'релативу"', Symbolae grammaticae in honorem Joanis Rozwadowski, II, Krakow.

Белић 1998: Александар Белић, Општа лингвистика, Изабрана дела Александра Белића, први том, књига I и II, Београд: Завод за уџбенике и наставна средства.

Вуковић 1938-1939: Јован Вуковић, „Говор Пиве и Дробњака”, Јужнословенски филолог, XVII, 1-113.

Грицкат 1954: И. Грицкат, О перфекту без помоћног глагола и сродним синтаксичким појавама, Београд: Српска академија наука и уметности.

Симић 1966: Радоје Симић, „Глаголска времена у зависним реченицама”, Наш језик, XV, св. 1-2: 1-57; 3-4: 121-157.

Станојчић 2010: Живојин Станојчић, Граматика српског књижевног језика, Београд: Креативни центар.

Стевановић 1957: Михаило Стевановић, „Начин одређивања значења глаголских времена", Јужнословенски филолог, XXII, 19-48.

Стевановић 1976: Михаило Стевановић, Функиије и значења глаголских времена, Београд: Српска академија наука и уметности, посена издања CDXXII, Одељење језика и литературе 20.

Стевановић 1991: Михаило Стевановић, Савремени срискохрватски језик II, 5. издање, Београд: Научна књига.

Стојановић 1921: Љубомир Стојановић, „О значењу и употреби глаголских облика у реченицама”, Јужнословенски филолог, II, 188-194. 
Jelena R. Jovanović Simić

\section{A. BELIĆ'S AND BELGRADE LINGUISTIC SCHOOL DOCTRINE ON MEANING AND USAGE OF TENSES}

\section{Summary}

Paper brings the review of verbal tenses meanings and usage formulated by A. Belić and his nearest collaborators and followers. As the central moment, author takes in consideration the notions of indicative, relative and mode moods in Serbian. 